\title{
Analysis Factors Affecting Lenders Intention In P2p Lending Platform Using Utaut2 Model
}

\author{
Angelina $^{\text {a }}$, Elizabeth Kurniadi ${ }^{\text {b }}$, Gianne Gladisca Hendityasari ${ }^{\text {c }}$, DR. Minsani Mariani, M.B.A. ${ }^{\text {d }}$ \\ a,b,c,d Binus University, Indonesia \\ angelina010@binus.ac.id, ${ }^{\mathrm{b}}$ elizabeth.kurniadi@binus.ac.id, ${ }^{\mathrm{c}}$ gianne.gladischa@binus.ac.id, ${ }^{\mathrm{d}}$ mmariani@binus.edu
}

Article History: Received: 10 November 2020; Revised 12 January 2021 Accepted: 27 January 2021; Published online: 5 April 2021

\begin{abstract}
Peer-to-Peer (P2P) lending platform is relatively new to Indonesian market and it managed to dominate Financial Technology in Indonesia by 2019. This fast growth is influenced by simple borrowing and lending activity regulation compared to more traditional markets like banks. Most of previous studies had been focusing on borrowers' side whereas the lender's side was minimally highlighted. Unified Theory of Acceptance and Use of Technology 2 (UTAUT2) is used to analyze key factors that affect the usage of P2P Lending with addition of trust and risk. This research used SmartPLS to calculate the effect of each variable and found that effort expectancy, social influence, facilitating condition, trust, and risk have positive effects on lenders intention to use the P2P lending platform

Keywords: Peer-to-peer, lender, Lender Intention, SmartPLS, UTAUT2, Performance Expectancy, Effort Expectancy, Social Influence, Facilitating Conditions, Price Value, Trust, Risk
\end{abstract}

\section{Introduction}

Technology development has driven consumers to do transactions digitally like transfer money, bill payments, investment, and online loans. Financial Technology or known as FinTech is one of the foremost critical advancements forming the conventional financial industry by moving forward financial services' quality, cutting costs, and making a more diverse financial industry landscape (Wulan, 2017). In 2019, Financial Technology in Indonesia was dominated by P2P (Peer-to-peer) lending (43\%), digital payment (26\%), market provisioning (8\%) (Fintechnews Indonesia, 2019). For the P2P lending sector, it continuing to grew from January 2019 to March 2020 with growth 83\% and with OJK (Otoritas Jasa Keuangan) Regulation POJK No. 77/POJK.01/2016 regulating Technology-Based Lending and Borrowing activities in Indonesia, FinTech companies operating in Indonesia must be registered and monitored under OJK while coordinating with the Ministry of Communication and Information (Kominfo) to operate the platforms' websites and applications.

Barberis \& Christi (2016) explained that the advancement of Financial Technology in developing countries is driven by: (1) youthful era with portable gadgets, (2) inefficient financial and capital markets that bring openings to casual choices, (3) comfort over trust, and (4) less rigid information assurance and competition. Peer-to-peer (P2P) lending platform is still nascent in Indonesia but it brings immediate impact towards economic growth. The industry growth is massive and embraces new markets, especially Micro and Small Medium Entrepreneurs (MSMEs), that face challenges to be served properly by existing conventional financial services institutions. There are more than 50 million MSMEs in Indonesia and about 70\% of them are unbankable (OJK, 2020). In doing business, additional capital is needed to expand their business, and mostly it comes from loans. P2P lending platform provides financial loans that have a relatively simpler and easier procedure.

While there are numerous potential FinTech further growth, these are also balanced against challenges that may be faced by FinTech sectors, especially in P2P lending platforms. The main challenge is the growth of lenders is not matched with the growth of borrowers. According to the OJK (2020) report, in July 2020, borrower accounts were 26.5 million accounts (increase $132 \%$ yoy), while lender accounts were 0.6 million accounts (increase $28 \%$ yoy). There is a huge gap between borrower accounts and lenders accounts, which could result in unsuccessful transactions.

Another challenge is Illegal FinTech has been growing rapidly disrupting the industry and the public are strongly urged by OJK to remain vigilant in making the lending decisions so they will not get engaged with the illegal FinTech platforms. Furthermore for lenders' side, regulations remain unclear hence if any disputes happen between lenders and P2P platforms, lenders should bear the risks - the loss of investment, the misuse of lending funds, the possibility of platform failure and bankruptcy (Duwitmu, 2019). While there are licensed P2P platforms 
who collaborate with insurance brokers to cover the loss, it was never fully-covered and not every platform has provided this alternative up until now. These efforts remain unclear whether it is sufficient or not to protect lenders as there is an information distortion.

A pre-survey questionnaire done on $5^{\text {th }}-6^{\text {th }}$ September 2020 aimed at the population who have an active P2P account in the Java Island area, 32 from 50 respondents (64\%) answered that they know about P2P lending, but only $37,5 \%$ have ever been a lender. Although the majority know about P2P lending, there is still a huge disparity between knowing P2P lending and the drives to being a lender.

A study done by Adityasari, Firmansyah \& Gunadi (2020) identified that P2P lending in Indonesia has problems in public distrust in using the platform. As of June 2019, there were 4,500 complaints related to FinTech lending to Legal Aid Institutions (LBH) and 1,230 illegal FinTech lending companies that have been investigated by the Investment Alert Task Force (SWI). Previous research done by Wang, et al. (2016) and Sundjaja \& Tina (2019) also supported that illegal FinTech had significantly influenced trust especially on lenders' lending intentions.

A research done by Amalia, Dulimunthe \& Triono (2020) also concluded that protection policy are much very needed for lenders as they are positively affecting lenders' intentions, such as written disclaimers of risks, platforms credit analyst of borrowers and platforms responsible towards lenders regarding bad debts and/or insurance protection. Various platforms carried out a series of protection policies and yet it still remains unclear whether it is useful and sufficient enough to protect lenders from lending risk in the platforms, and many of the P2P platforms' policies usually declare disclaimers that all of the credit risk and failure to repay will be fully borne by lenders.

In Indonesia, information asymmetry is still a common problem because the $\mathrm{P} 2 \mathrm{P}$ lending platform is still being born and growing hence there are no proper regulations for lenders (Afaf, 2017). Until now, it was unclear whether the safeguards offered by P2P lending platforms were sufficient to protect lenders from risk and maintain their trust. Previous existing research has focused mainly on the borrower side, it pays less attention to lenders' intention to use P2P lending platforms. With the absence of proper regulations for lenders, which creates high risk and low trust in the use of P2P lending, this has resulted in the public not knowing about $\mathrm{P} 2 \mathrm{P}$ which could have been a business opportunity to contribute to economic growth. Given that P2P lending platform is a technologybased application, this study uses the Unified Theory of Acceptance and Use of Technology 2 (UTAUT2) model which aims to analyze the factors affecting the lending intention to use P2P lending platforms in Indonesia (Soegesty et al. 2020). In this research, UTAUT2 model with performance expectancy, effort expectancy, social influence, facilitating conditions and price value, as factors are used with additional trust and risk factors. Therefore the research questions are as follow;

1. Do performance expectancy, effort expectancy, social influence, facilitating conditions, and price value in the UTAUT2 model have a positive effect on lenders intention to use the P2P lending platform?

2. Does trust have a positive effect on lenders intention to use the P2P lending platform?

3. Does risk have a positive effect on lenders intention to use the P2P lending platform?

This study focuses on the effects of performance expectancy, effort expectancy, social influence, facilitating conditions, price value, risk, and trust effect on Indonesia's lender's intention to use the P2P lending platform. Indonesia's Java Island active P2P lending platforms, lenders who have had lending record and/or experiences in P2P lending platforms and is still remain active lending and lenders who have successfully registered as lenders in P2P lending platforms but never had a real lending record and/or experiences in P2P lending platforms are the focus in this study. Therefore, those who had never had record and/or real experiences in P2P lending platforms will not be covered for their intention to lend in this research. The study is done through simple random sampling with the utilization of questionnaires to the lenders in the Java Island area.

\section{Literature Review}

A business innovation and the newest technology that can change financial services to be more effective is known by the public as financial technology (Riantama, Suardhika, and Yuesti, 2020). With this technology, people can easily make investments and loans online as well as replacing conventional bank services. One of the financial technologies that people can use for online investment and loans is peer-to-peer (P2P) lending. P2P lending is a platform that can lend funds without a mediator and the lending activities or transactions can be done through the internet (Septiani, Sumarwan, Yuliati Noor, and Kibrandoko, 2020). The usage of P2P lending is closely related to the internet and technology-based applications that can be studied using the Unified Theory of Acceptance and Use of Technology 2 (UTAUT2) model. UTAUT2 focuses on the acceptance and use of technology in the context of applications. UTAUT2 includes several variables such as performance expectancy, effort expectancy, social influence, facilitating conditions and price value. 
Performance expectancy which is the level of belief in a technology system that can help in achieving better performance. Performance expectancy can also be characterized as the degree to which the utilization of this innovation can give benefits for users to carry out certain activities (Yaseen and Qirem, 2017). According to Ain et al. (2016) states that there is a direct impact of performance expectations to intention to use financial technology. Therefore, the performance expectancy can be seen to what extent the use of P2P lending platforms can benefit lenders for carrying out certain activities on the $\mathrm{P} 2 \mathrm{P}$ lending platform, and the hypothesis is:

\section{$\mathrm{H}_{1}$ : Performance Expectancy has a positive effect on lenders intention to use P2P lending platform}

Effort expectancy is related to use in technology systems. According to Yaseen and Qirem, 2017, effort expectancy can be defined as the level of success and complexity in a particular technology. This can be expressed as a measurement of the extent to which the level of success and complexity of (P2P platforms can reach consumers so that they are encouraged to become lenders on P2P platforms. Hence, the proposed hypothesis is:

\section{$\mathrm{H}_{2}$ : Effort Expectancy has a positive effect on lenders intention to use P2P lending platform}

Social influence is the level at which someone will get recognition by the social environment when using a new technology system. Social influence provides views on where an individual perceives other people as having an obligation to use certain technology (Yaseen and Qirem, 2017). According to Ain et al. (2016) reported that individuals are socially affected by their peers' convictions around e-services, which in this way impacts their behavior to utilize e-services. The adoption of a P2P lending platform service can mean where P2P lenders perceive that others need to believe they need to receive and use $\mathrm{P} 2 \mathrm{P}$ services. Based on this belief, the proposed hypothesis is:

\section{H3: Social Influence has a positive effect on lenders intention to use P2P lending platform}

Facilitating conditions are regarding resources that will help lenders easily use a technology system. Lack of resources will weaken the assistance which will result in the absence of timely support and information provided is neither clear nor complete. According to Ain et al., 2016, restricted assets on technology will prevent users from tolerating the innovation, consequently slowing down the adoption process of the innovation. Where a person has arranged to do or not perform certain behaviors, it can be said as a facilitating condition (Correa, 2019). This means that having complete resources such as clear information on the peer-to-peer $(\mathrm{P} 2 \mathrm{P})$ lending platform will make it easier to reach individuals who will become lenders on the platform's peer-to-peer (P2P) service and the hypothesis is proposed as follow:

\section{H4: Facilitating Conditions has a positive effect on lenders intention to use P2P lending platform}

In general, every individual will take advantage of the product or information if there are benefits obtained from it that are greater than the costs provided by purchasing the product or correct information which is called the price value (Allazam et al., 2018). Price value is regarding perception of the amount of benefits compared to costs and it is a consumer's perceived tradeoff between the seen benefits of the applications and the money related benefits (Septiani, Sumarwan, Yuliati Noor, and Kibrandoko, 2020 and Albugami \& Belaaj, 2016). Based on this understanding, the hypothesis is:

\section{H5: Price Values has a positive effect on lenders intention to use P2P lending platform}

Trust is one of the aspects that influence consumers in using mobile e-commerce. All aspects of human life are based on a belief, including various relationships and objects and objects of belief that combine risks and expectations that have high expectations associated with the risks (Assegaff, 2017). In a research by Yang and Lee (2016), trust is divided into two dimensions: (1) a person accepts the unwavering quality and constancy of other people and (2) a person will feel better if they deal with reliable people. In P2P lending, especially on the lender's side, they will be faced with uncertainty. Therefore the trust in P2P will be an important factor. This statement is also supported by previous research by Wang, et al. (2016), Sundjaja \& Tina (2019), Suryono, et al. (2019) that claimed trust significantly influenced lenders' lending intentions. Hence $\mathrm{H}_{6}$ as below;

\section{H6: Trust has a positive effect on lenders intention to use P2P lending platform}

Risk is a multidimensional construct, six components of risk agreed upon by most academics relating to financial, performance, social, privacy and time loss (Assegaff, 2017). The risk in transactions through P2P lending platforms is greater than traditional transactions through financial institutions such as commercial banks that have complete access to information and have preventive instruments in place. Asymmetric information held by commercial banks can anticipate the high risk while P2P lending platform has relatively low information which can result in high-risk of borrowers do not pay the loan on time and the lenders should take cautious choice from the huge number of accessible credit demands that takes after with a high-risk of vulnerability and hazard (Xu and Chau, 2018). Lenders on P2P lending platforms do not demand as many requirements as financial background 
information, credit history, income, and borrower work as performed by commercial banks but this results in higher loan repayment rates and defaults. According to Liu and Xia (2017), this is due to a lack of legal policies, non-standard technical regulations, imperfect credit systems and asymmetric information resulting in $\mathrm{P} 2 \mathrm{P}$ lending platforms causing many problems such as legal and regulatory risks, technology risk, management risk and credit risk that can affect the development of $\mathrm{P} 2 \mathrm{P}$ lending platforms. There is a risk involved in a $\mathrm{P} 2 \mathrm{P}$ lending platform that will affect the intention to use a $\mathrm{P} 2 \mathrm{P}$ lending platform, the proposed hypothesis $\mathrm{H}_{7}$ as follows;

\section{H7: Risk has a positive effect on lenders intention to use P2P lending platform}

The intention to use is the intention of each individual to use certain technology for each different activity so that it can be explained as an intention to use (Ain et al., 2016). The intention to use is determined by the frequency of use of information technology (Correa.P, 2019). The intention to use a technology can be analyzed by the strength of the commitment of each individual involved through the intention to use it. It is imperative in measuring the success of a technology by analyzing the intention to use the technology.

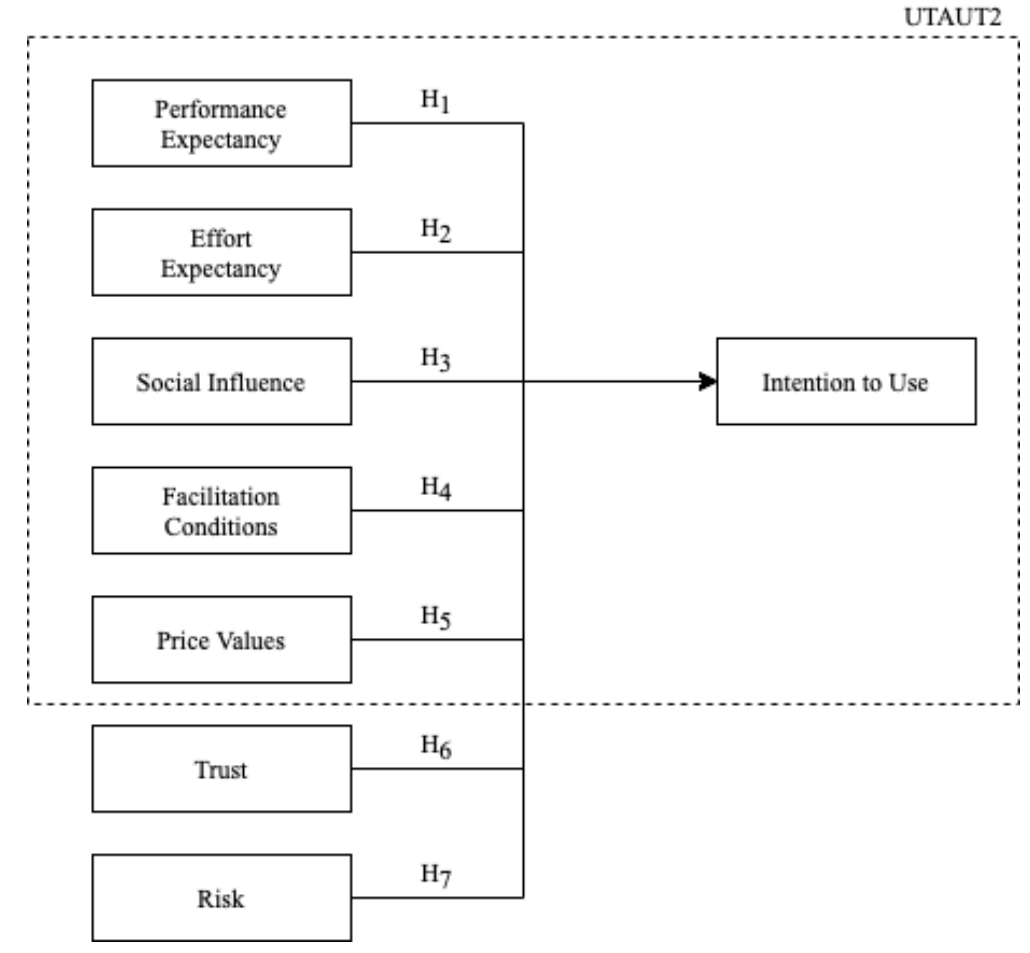

Figure 1. Research Framework

Source: Researchers (2021)

From the conceptual framework above, this research modified UTAUT2 model independent variables $\left(\mathrm{H}_{1}, \mathrm{H}_{2}\right.$, $\left.\mathrm{H}_{3}, \mathrm{H}_{4}, \mathrm{H}_{5}\right)$ with additional independent variables - trust and risk $\left(\mathrm{H}_{6}, \mathrm{H}_{7}\right)$ to determine the relationship towards lenders' intention to use peer-to-peer (P2P) lending as the dependent variables. Using this conceptual framework, we may determine the level of importance for each variable hence identifying the most pference factors that contribute the most when lenders' consider their intention to use a P2P lending platform.

\section{Research Methods}

This study uses quantitative methods which is a research method that was built upon philosophy and positivism used to identify certain populations and/or samples (Sugiyono, 2017:8). The research process uses deductive-quantitative methods which aim to answer the problem formulation using concepts and theories so that it can form a hypothesis. This type of research is a descriptive approach carried out to find out the value of each variable, either one or more variables without making a relationship or comparison with other variables which aims to provide a description of an objective state (Sujarweni Wiratna,V., 2015:49), where in this case the P2P lending industry is still relatively new and most of previous studies had been focusing on the borrowers' side whereas the lender's side was minimally highlighted. Descriptive studies are usually carried out to carefully chronicle the current event that is taking place or currently happening and enables researchers to compute and report the description of the event accurately and precisely (Babbie, 2012:116).

In quantitative research, research strategies that are used are field studies and survey methods. Field study is the direct observation of problems that are currently still in progress (or happening) and through the observations - 
theories are often built upon (Babbie, 2012:106). This study used a survey method to collect data and information directly from respondents (Sugiyono, 2017:23). The unit of analysis are individuals who have tried and/or used, and also individuals who have never tried and/or P2P lending platforms. Data collection was collected at once in a certain time which is called cross-sectional study.

The research design that is used is causal associative research which examines the relationship between two or more variables that have 3 forms of relationship. In addition for casual types of relationship it is free of cause and effect where there are variables called as performance expectations $\left(\mathrm{X}_{1}\right)$, effort expectancy $\left(\mathrm{X}_{2}\right)$, social influence $\left(\mathrm{X}_{3}\right)$, facilitating conditions $\left(\mathrm{X}_{4}\right)$, price values $\left(\mathrm{X}_{5}\right)$, trust $\left(\mathrm{X}_{6}\right)$, and risk $\left(\mathrm{X}_{7}\right)$ have an impact on intention to use (Y). Furthermore, studies also use primary data sources. Primary data source is a source of data directly provided to data collectors (Sugiyono, 2017: 137).

Sampling plans for this research uses simple random sampling with a population of active lenders in Indonesia's P2P lending platform across Java Island area which according to OJK data (2020) accumulated around 546,058 lenders. To draw a more detailed sampling frame from the lenders based on OJK data, all active lenders across Java Island area in P2P lending platforms will be include in this research which was categorized into three major lenders type for further research purposes: (1) active lenders who has had lending record and/or experiences in P2P lending platforms and is still remain active lending and (2) lenders who has successfully registered as lenders in $\mathrm{P} 2 \mathrm{P}$ lending platforms but never had a real lending record and/or experiences in $\mathrm{P} 2 \mathrm{P}$ lending platforms. Data processing and analysis was processed using partial least square-structural equation modeling (PLS-SEM) with the use of SmartPLS 3.0 software. Hussain \& Endut (2018), referring to Cohen (1992), recommend that sample size can be driven by the number of arrows pointing at a construct. As per their recommendations, in this research there are 7 (seven) arrows indicating this research target latent variable (Figure 1), hence the minimum sample size in significance level $5 \%$ is 137 respondents.

\section{Results And Discussions}

The data collection of this research was conducted using a questionnaire technique using Google form on January, $7^{\text {th }}$ up to January $12^{\text {th }} 2021$. The questionnaire form was distributed to the Java Island for lenders of the P2P Lending platform and potential lenders who had never tried the P2P Lending platform. Respondents data received until the specified time were 152 respondents, there are $55 \%$ male and $45 \%$ female with the majority born between 1980-1999 about 89\% with mainly diploma and bachelor degree $78 \%$. These respondents were mostly active employees with working experiences ranging from 1-5 years $(64 \%)$ and salary mostly ranging from Rp 5,000,000 - Rp 8,000,000 (42\%). The respondents consisted of 47\% respondents were active lenders who have had lending experiences in P2P lending platforms and still remain active lending, 38\% respondents had successfully registered as lenders but never had real lending experiences in P2P lending platforms, and the rest $15 \%$ had neither registered as lenders nor lending experiences. Thus, the respondents who had met the characteristics of this study are 137 respondents $(85 \%)$. Based on the information that has been collected through a Google Forms survey, the researcher wants to identify whether performance expectancy, effort expectancy, social influence, facilitating conditions, price value, trust and risk have an influence on the lenders' intentions to use the P2P Lending platform.

Validity and reliability tests were done using SmartPLS 3.0 software with a reflective model. The coefficient of determination or R-Square Adjusted for the latent variable Intention to Use is 0.726 . This shows that the latent variables Performance Expectancy, Effort Expectancy, Social Influence, Facilitating Conditions, Price Value, Trust, Risk explain $73 \%$ of the variance of Lending Intention to use P2P lending platforms. It can be excluded that the Intention to Use has a strong endogenous construct determination because it has an R-Square Adjusted value of more than 0.67 (Jabbar, et. al 2020). Based on respondents' data, it is showed that in latent variable performance expectancy, respondents feel the P2P Lending platform can increase the chance of getting additional income by $88 \%$, on the latent variable effort expectancy, respondents feel the P2P Lending platform is very easy to learn at $87.8 \%$, for the latent variable social influence, respondents' colleagues suggested using the P2P Lending platform by $89.4 \%$, for the latent variable Facilitating conditions, respondents felt they had the knowledge needed to use the P2P Lending platform by $87.4 \%$, on the latent variable price value, respondents felt the need for rules and regulations in the P2P Lending platform transparently amounting to 87.2\%, on the latent variable trust, respondents did not doubt the integrity of the $\mathrm{P} 2 \mathrm{P}$ Lending platform, on the latent variable risk, respondents felt the $\mathrm{P} 2 \mathrm{P}$ Lending platform will not risk their self-image amounted to $86.4 \%$ and on latent variable intention to use, respondents will want to have access to use the P2P Lending platform by $88.1 \%$. The validity test of this study can be seen in Table 1 and latent variables can be declared valid if the Average Variance Extracted (AVE) value is $>0.5$. 
Table 1. Validity Test

\begin{tabular}{|l|c|}
\hline \multicolumn{1}{|c|}{ Latent Variable } & $\begin{array}{c}\text { Average Variance Extracted } \\
\text { (AVE) }\end{array}$ \\
\hline Performance Expectancy & 0.673 \\
\hline Effort Expectancy & 0.711 \\
\hline Social Influence & 0.736 \\
\hline Facilitating Conditions & 0.663 \\
\hline Price Value & 0.695 \\
\hline Trust & 0.687 \\
\hline Risk & 0.752 \\
\hline Intention to Use & 0.644 \\
\hline
\end{tabular}

Source: Researchers (2021)

Based on table 2 it can be stated that all latent variables have an Average Variance Extracted (AVE) value of $>0.5$, so it can be concluded that all latent variables are valid. After that, a reliability test was carried out using Composite Reliability values. Based on table 2, the composite reliability value of each latent variable has a value of $>0.7$ so it can be stated that the internal consistency reliability of each variable is reliable.

Table 2. Reliability Test

\begin{tabular}{|l|c|l|}
\hline \multicolumn{1}{|c|}{ Latent Variable } & Composite Reliability & Results \\
\hline Performance Expectancy & 0.911 & Reliable \\
\hline Effort Expectancy & 0.924 & Reliable \\
\hline Social Influence & 0.933 & Reliable \\
\hline Facilitating Conditions & 0.907 & Reliable \\
\hline Price Value & 0.919 & Reliable \\
\hline Trust & 0.916 & Reliable \\
\hline Risk & 0.938 & Reliable \\
\hline Intention to Use & 0.900 & Reliable \\
\hline
\end{tabular}

Source: Researchers (2021)

The hypothesis of this study was tested using the bootstrapping function in the SmartPLS 3.0 software. Hypothesis testing can be seen from the t-statistical value (1.96) and the probability value, namely the alpha value of $5 \%$. The criteria for the hypothesis are accepted or $\mathrm{H}_{\mathrm{a}}$ is accepted when the $\mathrm{t}$-statistic is $>1.96$ and $\mathrm{p}$ value is $<0.05$.

Table 3. Multiple Regression Test

\begin{tabular}{|c|c|c|c|c|c|c|}
\hline Correlation of Variables & $\begin{array}{c}\text { Original } \\
\text { Sample (O) }\end{array}$ & $\begin{array}{c}\text { Sample } \\
\text { Mean (M) }\end{array}$ & $\begin{array}{c}\text { Standard Deviation } \\
\text { (STDEV) }\end{array}$ & $\begin{array}{c}\text { T Statistics } \\
(|\mathrm{O} / \mathrm{STDEV}|)\end{array}$ & P Values & Results \\
\hline $\begin{array}{l}\text { Performance Expectancy } \rightarrow \\
\text { Intention to Use }\end{array}$ & -0.31 & -0.229 & 0.172 & 1.799 & 0.072 & $\mathrm{H}_{0}$ Rejected \\
\hline $\begin{array}{l}\text { Effort Expectancy } \rightarrow \text { Intention to } \\
\text { Use }\end{array}$ & 0.924 & 0.623 & 0.097 & 6.579 & 0 & $\mathrm{H}_{0}$ Accepted \\
\hline $\begin{array}{l}\text { Social Influence } \rightarrow \text { Intention to } \\
\text { Use }\end{array}$ & 0.721 & 0.603 & 0.223 & 3.234 & 0.001 & $\mathrm{H}_{0}$ Accepted \\
\hline Price Value $\rightarrow$ Intention to Use & -0.286 & -0.23 & 0.164 & 1.74 & 0.082 & $\mathrm{H}_{0}$ Rejected \\
\hline Trust $\rightarrow$ Intention to Use & 0.375 & 0.31 & 0.178 & 2.104 & 0.035 & $\mathrm{H}_{0}$ Accepted \\
\hline Risk $\rightarrow$ Intention to Use & 0.156 & 0.18 & 0.076 & 2.044 & 0.041 & $\mathrm{H}_{0}$ Accepted \\
\hline
\end{tabular}

Source: Researchers (2021)

Based on the results of bootstrapping in SmartPLS 3.0 software, in hypothesis 1 performance expectancy and intention to use has no significant relationship with the t-statistics value compared to t-table value of $1.799<1.96$ and has a P-value of $0.072>0.05$ with coefficient of -0.310 indicating a negative relationship. In the digital mobile technology context, performance expectancy is mostly associated with the transaction speed and the ability of the platforms to make the transaction more efficient and convenient thus improving the lender's productivity. 
This findings that performance expectancy does not have a significant effect on lenders' intention to use may conclude that lenders in Indonesia do not put the transaction efficiency as priority to improve their productivity, whereas this result is also supported by Yaseen \& Qirem (2018) where the benefits of the applications and their ability to work to increase productivity have no influence on society to become a lender on a P2P platform.

As of Hypothesis 2, the effort expectancy and intention to use has a significant positive relationship with the tstatistics value compared to the t-table value of $6.579>1.96$ with a P-value of $0.000<0.05$ with coefficient 0.924 indicating a positive strong relationship that the ease of use of peer-to-peer (P2P) platforms will strongly encourage lenders' intention to lending in the platforms. This statement is strongly aligned with Hoque \& Sorwar (2017) and Saxena, S., \& Janssen, M. (2017). Based on this research, effort expectancy has the highest effect in influencing lenders' intention to use P2P lending platforms.

In hypothesis 3 , social influence with intention to use has a significant positive relationship with the t-statistics value compared to the t-table value of $3.234>1.96$ with a P-value of $0.001<0.05$ and coefficient of 0.721 whereas this reveals that the social factors of the lenders' surrounding will provide an influence towards lenders' intention to use. The more the social environment of the lenders encourages and/or actively participates in using peer-to-peer ( $\mathrm{P} 2 \mathrm{P})$ lending platforms will also further motivate lenders' intention to use.

Meanwhile, in hypothesis 4, facilitating conditions with intention to use has a significant positive relationship with the t-statistics value compared to the t-table value of $7.958>1.96$ with a $\mathrm{P}$-value of $0.000<0.05$ and coefficient of 0.544 . The compatibility of peer-to-peer ( $\mathrm{P} 2 \mathrm{P})$ platforms and the help provided in the platforms will have influence on lenders' intention to use. This result is supported by Issac et al. (2018).

As of hypothesis 5, price value and intention to use has no significant relationship with the t-statistics value compared to the $t$-table value of $1.740<1.96$ and has a P-value of $0.082>0.05$ with coefficient -0.286 indicating a negative relationship.The negative relationship between price value and intention to use can be caused by non monetary requirement in order for lenders to use P2P platforms. In other words, P2P lending platforms do not require more commitment, hence lenders are free to create a lending account, but not necessarily do a lending process (Correa.P, 2019).

In hypothesis 6 , trust with intention to use has a significant positive relationship with the t-statistics value compared to the $\mathrm{t}$-table value of $2.104>1.96$ with a P-value of $0.035<0.05$ and coefficient 0.375 . The integrity and the regulatory of the P2P lending platforms will be highlighted by the lenders before they actually lend in the platforms. Furthermore, the ability of the platforms to secure the lenders' repayment rights and bad debts insurance will also encourage lenders' intentions (Liu \& Xia, 2017).

Meanwhile, in hypothesis 7, risk with intention to use has a significant positive relationship with the t-statistics value compared to the $t$-table value of $2.044>1.96$ with a P-value of $0.041<0.05$ and coefficient 0.156 . Peer-topeer (P2P) platforms' ability to provide accurate lending information and secure lenders' privacy information in lending activity will decrease perceived risk by lenders.

\section{Conclusions}

From the research result that has been analyzed, it has been found that there are five variables that significantly influence the intention of lenders' to use lending intentions in P2P lending platforms. These variables are; Effort Expectancy, Social Influence, Facilitating Conditions, Trust, and Risk. This modified UTAUT 2 Model has strong explanatory power with R-Square valuing $72.6 \%$ indicating that it can be strongly used to explain the lenders' intention to use P2P lending platforms. Meanwhile, Performance Expectancy and Price Values are proven to have no significant relationship towards lenders' Intention to Use.

The result in this research found that effort expectancy and facilitating conditions will encourage lenders' lending intentions. Both of these two variables are closely related, the effort expectancy is associated with the knowledge of lenders' on the platforms whereas if they have full understanding of the platforms and how it works, it will drive their intention to use higher. Meanwhile, facilitating conditions is associated with the resources potential lenders' have and the services of customer service to drive them to use the platforms. These findings may encourage peer-to-peer (P2P) lending platforms to consider further developing their ease of use in the application, providing more transparent and comprehensive information to support the lender's in-apps journey, such as borrowers' loan information, interest calculation and various customer service contact information.

Meanwhile, social influence may be improved by the peer-to-peer (P2P) lending platforms through brand marketing providing a more educated and comprehensive information of the platforms to avoid public negative perception of the industry due to increased illegal platforms. The lack of knowledge about the peer-to-peer (P2P) industry and the negative news of illegal platforms had decreased the trust of active lenders and disinterested potential lenders. 
Furthermore, the level of trust and risk of lenders' towards the platforms are proven to significantly influence their lending intention. Besides than providing a positive brand image marketing and education to drives the trust of lenders, the peer-to-peer (P2P) lending platforms should always inlign their commitment to Financial Services Authority (OJK) giving lenders' a more secure platform and collaborate with insurance to cover in case of bad debts to secure lender's rights of receiving repayment. Furthermore, working closely with various credit scoring aggregators to maintain the P2P platforms risk management accuracy, thus minimizing the risk of lenders' unpaid.

On the other hand, the regulatory authorities in Indonesia should arrange in a more detailed and balanced manner with the aim of further securing lenders' rights. Along with its emerging development, regulators should tighten regulations while taking account of the flexibility of the industry and the supervision to minimize the asymmetric information between lenders and borrowers. Lenders would prefer a complete and valid information of the loan they are choosing and borrowers tend to hide information in hopes of obtaining a higher loan with lower interest and this is where the regulators need to minimize the risk of asymmetric information to encourage the lenders' account and values in Indonesia. While it is undeniable that the peer-to-peer (P2P) lending industry is still relatively mild compared to other financial services institutions, peer-to-peer (P2P) lending brings immediate impacts towards economic growth due to the numbers of MSMEs that are still untouchable by conventional financial services institutions.

\section{Limitations And Future Research}

There are few limitations in this research due to (1) specific geographic context of the respondents focusing on Java Island especially Jabodetabek area and (2) the specific age of respondents in which the majority are born between 1980-1999. Consequently, this result may raise concerns for the generalizability of the discoveries. Future study may focus on expanding the geographic limit towards national level in Indonesia and additional demographic factors such as income of the lenders to further analyze the personal variables such as trust and personal initiatives that are affecting the lenders' intention to use. Future study may also expand the data collection adoption to both quantitative and qualitative approaches to further analyze and gather more in-depth views from the lenders through interviews or face-to-face interaction analyzing lenders' opinions and insights for the problem

\section{References}

Adityasari, N., Firmansyah, R.K. \& Gunadi, W. (2020). Analyzing the Use of P2P Lending Mobile Applications in Greater Jakarta. International Journal of Advanced Trends in Computer Science and Engineering. Vol. 9(2). Page. 2010-2020.

Afaf, A. (2017). Perlindungan Hukum Bagi Pemberi Pinjaman Terhadap Risiko Gagal Bayar Dalam Perjanjian Peer To Peer Lending.

Ain, N. Kaur, K. \& Waheed, M. (2016). The Influence of Learning Value on Learning Management System Use: An Extension of UTAUT 2. Journal of Information Development. Page. 1-17.

Albugami, M. \& Belaaj, M. (2016). The Continued Use of Internet Banking: Combining UTAUT2 Theory And Service Quality Model. Journal of Global Management Research. Page: 11-28

Allazam, M. Al-Sharo, Y. Allazam, K. (2018). Developing (UTAUT 2) Model of Adaptation Mobile Health Application in Jordane E-Government. Journal of Theoretical and Applied Information Technology. Vol. 96(12). 3846-3860.

Amalia, N., Dalimunthe, Z. \& Triono, R.A. (2020). The Effect of Lender's Protection on Online Peer-to-Peer Lending in Indonesia. Vision 2020: Sustainable Economic Development and Application of Innovation Management.

Assegaff, S. (2017). Analisis Perilaku User pada Pemanfaatan Layanan Pemesanan Tiket Online pada Aplikasi Mobile (Perspektif Kepercayaan dan Resiko oleh Konsumen). Jurnal Manajemen Teknologi, 16(1), 2017,62 80.

Babbie, E. (2012). The Practice of Social Research, Thirteenth Edition, International Edition.

Barberis, J. \& Chisti, S. (2016). The Fintech Book: The Financial Technology Handbook for Lenders, Entrepreneurs and Visionaries, 1st Edition. Wiley, India.

Botsman, R. \& Rogers R. (2010). What's Mine is Yours: How Collaborative Consumption is Changing the Way We Live. New York: HarperCollins Publishers.

Celik, H. (2015). Customer Online Shopping Anxiety Within the Unified Theory of Acceptance and Use Technology (UTAUT) Framework. Asia Pacific Journal of Marketing and Logistics 28(2): 278-307.

Chao, C. (2019). Factors Determining the Behavioral Intention to Use Mobile Learning: An Application and Extension of the UTAUT Model. Journal Frontier in Psychology, 10(1652): 1-14.

Chen, Y. \& Salmanian, W. (2017). User Acceptance in The Sharing Economy. An Explanatory Study of Transportation Network Companies in China Based On UTAUT2. Finland: Jonkoping University.

Correa. P. (2019). Analysing the Acceptation of Online Games in Mobile Devices: An Application of UTAUT2. Journal of Retailing and Consumer Service. Vol. 50(1). 85-93. 
Duwitmu. (2019). P2P Peer to Peer Lending Indonesia | 5 Resiko Investasi Fintech. Available at https://duwitmu.com/investasi/5-resiko-investasi-fintech-p2p-lending-indonesia/amp/

Financial Bisnis. (2020). Fintech P2P Lending Indonesia Jadi Perhatian Dunia. Available at https://finansial.bisnis.com/read/20200824/563/1282566/fintech-p2p-lending-indonesia-jadi-perhatian-dunia

Fintechnews Indonesia. (2019). Indonesia's P2P Lending Sector Sees 642\% Growth in Disbursements. Available at https://intechnews.sg/34442/indonesia/p2p-lending-indonesia-growth/

Gusman, R. \& Ariyanti, M. (2019). Identification of the Factors Affecting the Adoption of the Use of Mygrapari Service Machines in Jakarta with The Unified Theory of Acceptance and Use of Technology 2 Model (UTAUT2). Asian Journal of Management Sciences \& Education 8(2): 1-12.

Hasudungan, T. \& Prasetio, A. (2019). Analysis of Factors That Influence Behavior Using Mobile Cellular Application AB with Unified Theory of Acceptance and Use of Technology 2 (UTAUT 2) in Millennial Customers of ABC in Jabodetabek and Jabar. Asian Journal of Management Sciences \& Education 8(1): 8394.

Hoque, R. \& Sorwar, G. Understanding Factors Influencing the Adoption of mHealth by the Elderly: An Extension of the UTAUT model. International Journal of Medical Informatics 101(1): 75-84.

Hussain, B. \& Endut, N. (2018). Application of SEM Using Smart PLS: Examining Decent Working Conditions of Small Enterprises. London: SAGE Publications Ltd.

Issac, O., Abdullah, Z., Aldholay, A., Ameen, Ali. (2018). Antecedents and Outcomes of Internet Usage within Organisations in Yemen: An Extension of the Unified Theory of Acceptance and Use of Technology (UTAUT) Model. Asia Pacific Management Review 191(1): 1-20.

Jabbar, M.N., Hussin, F. \& Nazli, M. (2020). The Intervening Coherence of Quality Management and Empowerment on the Relationship between Leader Behavior and Job Satisfaction Among University Lecturers. International Journal of Innovation, Creativity and Change 11(5): 27-48.

Jakarta Post. (2020). Fintech Lenders Struggle To Get Back Money, Bad Loan Ratio Reaches 7.9\%. Available at https://www.thejakartapost.com/news/2020/09/23/fintech-lenders-struggle-to-get-back-money-bad-loan-ratioreaches-7-9.html

Kim, C., Lee, I., Wang, T., Mirusmonov, M. (2015). Evaluating Effects of Mobile CRM on Employees' Performance. Industrial Management \& Data Systems 115 (4): 740-764.

Liu, W. \& Xia, L. (2017). An Evolutionary Behavior Forecasting Model for Online Lenders and Borrowers in Peer-to-Peer Lending. Asia-Pasific Journal of Operational Research. Vol. 34(1). Pages 1-14.

Ma, H.Z. \& Wang, X.R. (2016). Influencing Factor Analysis of Credit Risk in P2P Lending Based on Interpretive Structural Modeling. Journal of Discrete Mathematical Sciences \& Cryptography. Vol. 19(3). Page. 779-786.

OJK. (2020). Perkembangan Fintech Lending Juli 2020. Available at https://www.ojk.go.id/id/kanal/iknb/datadan-statistik/fintech/Documents/Perkembangan\%20Fintech\%20Lending\%20Periode\%20Juli\%202020.pdf

Riantama, E., Suardhika \& Yuesti, A. (2020). Financial Technology Application Success in the 4.0 Era. International Journal of Psychosocial Rehabilitation, Vol. 24(09). Hal. 2948-2962.

Septiani, H., Sumarwan, U., Yuliati Noor, L. \& Kibrandoko. (2020). Farmer's Behavioral Intention to Adopt Peer-to-Peer Lending Using UTAUT2 Approach. Jurnal Manajemen \& Agribisnis. Vol. 17(2). Hal. 107-116.

Septiani, H., Sumarwan, U., Yuliati Noor, L. \& Kibrandoko. (2020). Factors Encouraging The Use of Peer-toPeer Lending by Farmers. Russian Journal of Agricultural and Socio-Economic Sciences. Vol. 07(103). Hal. 72-81.

Soegesty, N.B., Fahmi, I. \& Novianti, T. (2020). Kajian Faktor Yang Memengaruhi Adopsi Sistem Pinjaman Peer To Peer Lending. Jurnal Manajemen Teknologi, 19(1), 2020,59-79.

Saxena, S., \& Janssen, M. (2017). Examining open government data (OGD) usage in India through UTAUT framework. Foresight (Cambridge): The Journal for Future Studies, Strategic Thinking and Policy, 19(4), 421- 436. DOI: $10.1108 /$ FS-02-2017-0003

Sugiyono. (2017). Metode Penelitian Kuantitatif, Kualitatif dan R\&D. Bandung: Alfabeta.

Sundjaja, A. M. \& Tina, A. (2019). The Factors of the Intention to Use P2P Lending Financial Technology (Fintech) Website at Jabodetabek Intervening By Perceived Value. International Journal of Recent Technology and Engineering, Volume 8 Issue 3, September 2019.

Surjaweni Wiratna, V. (2015). Metodologi Penelitian Bisnis dan Ekonomi. Yogyakarta: PUSTAKABARUPRESS.

Suryono, R.R., Purwandari, B. \& Budi, I. (2019). Peer to Peer (P2P) Lending Problems and Potential Solutions: A Systematic Literature Review. Procedia Computer Science Volume 161, 2019, Pages 204-214.

Wang, P., Zheng, H., Chen, D. \& Ding, L. (2016). Exploring the Critical Factors Influencing Online Lending Intentions. Financial Innovation 2015 1:8.

Wulan, V. R. (2017). Financial Technology (FinTech): A New Transaction in Future. Journal of Electrical Engineering and Computer Sciences Vol. 2, No.1, June 2017. 
Yang, Q. \& Lee, Y.C. (2016). Influencing Factors on the Lending Intention of Online Peer-to-Peer Lending: Lessons from Renrendai.com. The Journal of Information Systems 25(2):79-110.

Yaseen, S.G. \& Qirem, I.A.E. (2018). Intention to Use E-banking Services in Jordanian Commercial Banks. International Journal of Bank Marketing Vol. 36 No. 3, 2018 pp. 557-571.

$\mathrm{Xu}$, J. \& Chau, M. (2018). Cheap Talk? The Impact of Lender-Borrower Communication on Peer-to-Peer Lending Outcomes. Journal of Management Information Systems. Vol. 35, No.1, 2018. Pages 53-85.

\section{APPENDIXES}

APPENDIX 1. QUESTIONNAIRE

\begin{tabular}{|c|c|c|c|c|c|c|}
\hline No. & Questions & 1 & 2 & 3 & 4 & 5 \\
\hline \multicolumn{7}{|c|}{ Performance Expectation } \\
\hline 1 & I find a P2P platform useful for investments in my daily life. & & & & & \\
\hline 2 & P2P platform provides faster and more accurate loans. & & & & & \\
\hline 3 & P2P platform increases my productivity. & & & & & \\
\hline 4 & $\begin{array}{l}\text { Using P2P learning would improve my opportunity ro received additional } \\
\text { income. }\end{array}$ & & & & & \\
\hline 5 & Using P2P is beneficial for me. & & & & & \\
\hline \multicolumn{7}{|c|}{ Effort Expectancy } \\
\hline 6 & Learning how to use $\mathrm{P} 2 \mathrm{P}$ service is easy for me. & & & & & \\
\hline 7 & My interaction with P2P service is understandable. & & & & & \\
\hline 8 & It is easy for me to become skillful at using a P2P platform. & & & & & \\
\hline 9 & I find it easy to lend to the P2P platform as lenders. & & & & & \\
\hline 10 & I do not have difficulty in explaining the ease of use of P2P platforms. & & & & & \\
\hline \multicolumn{7}{|c|}{ Social Influence } \\
\hline 11 & People around me think that I should use a P2P platform. & & & & & \\
\hline 12 & My colleagues think that I should use a P2P platform. & & & & & \\
\hline 13 & People whose opinions that I value prefer that I use a P2P platform. & & & & & \\
\hline 14 & People who influence my behavior think that I should use a P2P platform. & & & & & \\
\hline 15 & Most of the people around me are using P2P lending platforms. & & & & & \\
\hline \multicolumn{7}{|c|}{ Facilitating Conditions } \\
\hline 16 & P2P is compatible with other technologies I use. & & & & & \\
\hline 17 & I have the necessary knowledge to use a P2P lending platform. & & & & & \\
\hline 18 & I have the necessary resources to use a P2P lending platform. & & & & & \\
\hline 19 & $\begin{array}{l}\text { I received necessary help from my surroundings when I am having a hard } \\
\text { time using a P2P lending platform. }\end{array}$ & & & & & \\
\hline 20 & $\begin{array}{l}\text { P2P lending platform support team is helpful when I am having a hard time } \\
\text { using it. }\end{array}$ & & & & & \\
\hline \multicolumn{7}{|c|}{ Price Values } \\
\hline 21 & Investing in a P2P lending platform provides many advantages. & & & & & \\
\hline 22 & The interest given is in accordance with the investment that I spend. & & & & & \\
\hline 23 & I am able to invest in the value I desire. & & & & & \\
\hline 24 & I received necessary information to invest in $\mathrm{P} 2 \mathrm{P}$ lending as lenders. & & & & & \\
\hline
\end{tabular}




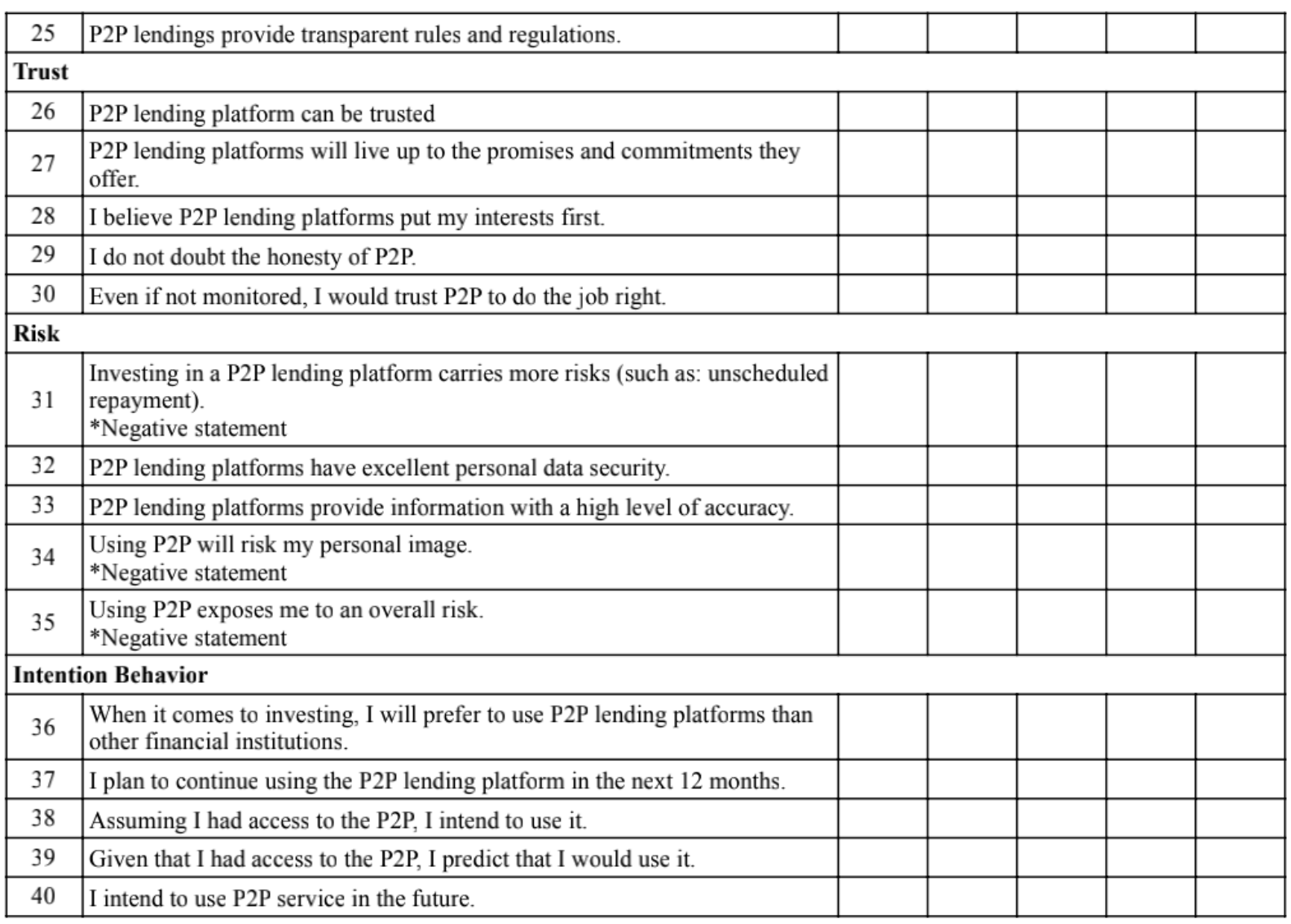

